\title{
Three Design Basis Accidents' Analysis on the HTR-10GT
}

\author{
Minggang Lang, Heng Xie, and Yujie Dong \\ Institute of Nuclear and New Energy Technology of Tsinghua University, Collaborative Innovation Center of Advanced Nuclear \\ Energy Technology, The Key Laboratory of Advanced Reactor Engineering and Safety, Ministry of Education, Beijing, China \\ Correspondence should be addressed to Yujie Dong; dongyj@tsinghua.edu.cn
}

Received 23 December 2016; Revised 14 April 2017; Accepted 7 May 2017; Published 5 June 2017

Academic Editor: Hidemasa Yamano

Copyright (c) 2017 Minggang Lang et al. This is an open access article distributed under the Creative Commons Attribution License, which permits unrestricted use, distribution, and reproduction in any medium, provided the original work is properly cited.

\begin{abstract}
The study simulated the design basis accidents (DBAs) sequences of the HTR-10GT core with THERMIX. When a DBA happens, the protection system will receive a scram signal which shall lead to active measures to shut down the reactor following it. In the paper, three typical DBA cases were studied. They include an accident induced by station blackout, a case caused by the withdrawal of one control rod out of the core by a mistake, and a case resulting from an earthquake, respectively. The simulation results illustrate that the fuel peak temperatures in the core during these accidents are $1066^{\circ} \mathrm{C}, 1201^{\circ} \mathrm{C}$ and $1067^{\circ} \mathrm{C}$, respectively. It is shown that the HTR-10GT has a good safety characteristic.
\end{abstract}

\section{Introduction}

Since Lohnert and Reutler proposed the concept of modular high-temperature gas-cooled reactor (HTGR) in the end of the 1970s, various countries have put a lot of attention on development of modular HTGR for its high degree of passive safety and the potential to provide high-temperature fluid for process heat applications $[1,2]$. Several reactors of various power levels have been constructed in the 20th century, such as AVR and THTR-300 in Germany, Peach Bottom (as the smaller test reactor) and Fort St. Vrain (as the demo plant) in USA, HTTR (30 MW thermal) in Japan, and HTR-10 (the $10 \mathrm{MW}$ high-temperature gas-cooled test reactor) in China. At present, all HTGRs except for HTTR and HTR-10 are in decommisioning since many years. China is designing and constructing its commercial demonstration HTGR plant which is called HTR-PM (high-temperature gascooled reactor-pebble-bed module) now.

China's HTR-10 was a pebble-bed modular test HTR, which was designed, constructed, and operated by Institute of Nuclear and New Energy Technology (INET) of Tsinghua University. In December of 2000, the HTR-10 reached criticality for the first time and in January of 2003 it achieved full power operation with a thermal power output of $10 \mathrm{MW}$ and a coolant outlet temperature of $700^{\circ} \mathrm{C}$ [3]. As time goes on, many planned commissioning tests have been performed on HTR-10 to test the performance of the spherical fuel elements and to demonstrate its passive safety characteristics. The designing codes used for the HTR-10 were also validated against the test results at the same time [4-7].

The HTR with a gas turbine in direct cycle mode promises higher electricity generation efficiency. To verify the technology, INET first plans to raise the outlet temperature to $750^{\circ} \mathrm{C}$ in the HTR-10 core with the same sphere fuels and to replace the steam generator with a gas turbine power conversion unit. The new designed reactor is named HTR-10GT, and its main operating parameters are listed in Table 1.

The preliminary scheme of the HTR-10GT is to replace the steam generator with a helium gas turbine, while keeping pressure boundary of the primary loop system and the layout of the reactor pressure vessel (RPV) unchanged. Figure 1 shows the layout and schematic of the HTR-10GT. The key parameters of the protection system of the HTR-10GT are similar to those of the HTR-10, but the parameters related to the secondary loop, such as flow rate of feedwater and steam fraction, do not apply. The limiting temperature of helium flow passing through the core inlet and outlet is increased by $50^{\circ} \mathrm{C}$ and $80^{\circ} \mathrm{C}$, respectively. In addition, the ratio between flow rates of the primary loop and the secondary loop in the HTR-10 is changed to a normalized value between the flow rate of the primary loop and the power of the gas turbine in the HTR-10GT. The detailed parameters of the 


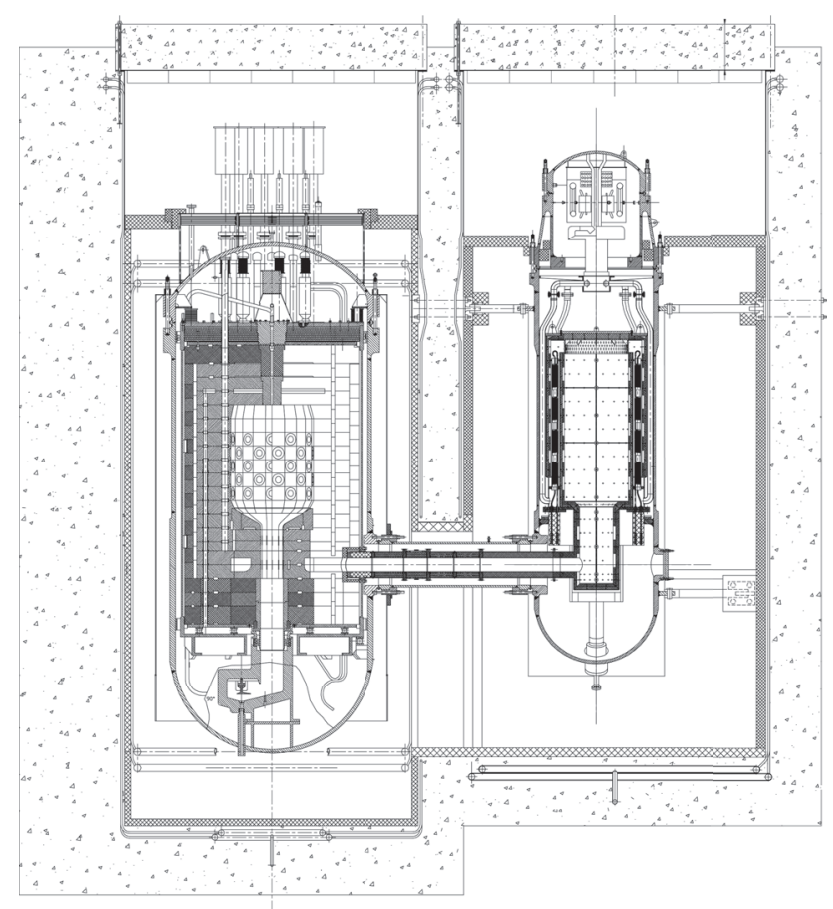

(a)

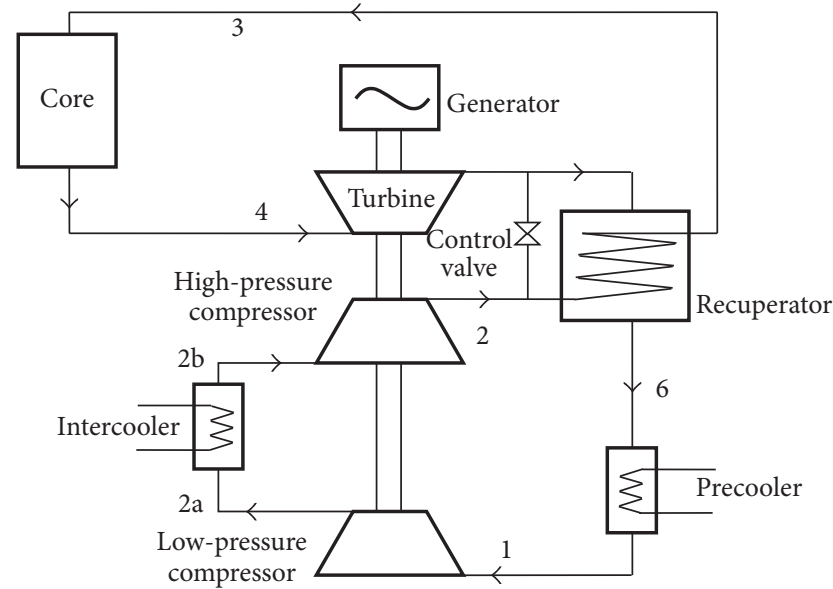

(b)

FIgURE 1: (a) Layout of HTR-10GT. (b) Schematic of HTR-10GT.

TABLE 1: Main operation parameters of HTR-10GT in comparison with HTR-10 and HTR-PM.

\begin{tabular}{lccc}
\hline Core & HTR-10GT & HTR-10 & HTR-PM \\
\hline $\begin{array}{l}\text { Thermal power, MW } \\
\text { Coolant inlet/outlet }\end{array}$ & 10 & 10 & $250 /$ unit \\
temperature, ${ }^{\circ} \mathrm{C}$ & $330 / 750$ & $250 / 700$ & $250 / 750$ \\
System pressure, $\mathrm{MPa}$ & 1.59 & 3.0 & 7.0 \\
Helium flow rate, $\mathrm{kg} / \mathrm{s}$ & 4.56 & 4.32 & 96 \\
\hline
\end{tabular}

protection system of the HTR-10GT are illustrated in Table 2. The operating temperatures of the components contained in reactor pressure vessel and hot gas duct rise as the helium temperatures at the core inlet and outlet increase. However, these temperatures remain well below the components design temperatures of the HTR-10, as a large safety margin has been taken into account.

The passive safety characteristics of the HTR-10 have been approved by the National Nuclear Safety Administration (NNSA) of China, after analysis of design basis accidents (DBAs) and beyond design basis accidents (BDBAs) was completed [8]. However, because of the differences between the main operating parameters of the HTR-10 and HTR10GT, China's nuclear regulations require that new safety analysis of the HTR-10GT be performed at operating and accidental states and certified. The paper studied three DBA cases induced by station blackout, by one control rod withdrawal out of the core by mistake, and by earthquake. Transient analysis of the three cases was performed using the THERMIX code, and safety characteristics of the HTR-10GT are discussed in detail in the paper. The results will be meaningful to the HTR-PM, as the helium temperature at the core outlet of the HTR-PM is similar to the HTR-10GT.

\section{Analysis Tools and Models}

The design basis accidents of HTR-10 were analysed with THERMIX, a thermal hydraulic code system developed by KFA-Jülich (now FZJ) of Germany. The THERMIX code has been applied for the simulation of the helium circulator trip ATWS test. THERMIX has been validated and verified against data from experiments performed at KFA [9], benchmark calculations for the GT-MHR [10], and extensive experimental programs carried out on the THTR-300 [11]. At present, the code is under further validation in INET through data of the tests on the HTR-10 to improve the design methodology for future HTGRs. In the study, THERMIX was used to analyse the DBAs of the HTR-10GT.

The general code structure of THERMIX adopts a twodimensional cylindrical geometry and consists of a generalpurpose steady-state or transient heat conduction code and a quasi-steady-state convection code. The code system consists of a two-dimensional transient solid temperature model (Thermix), a quasi-stationary gas flow model (Konvek), a primary loop model (Kismet), a point-neutron kinetics model (Kinex), and a graphite corrosion model. THERMIX is able to analyse the thermal hydraulic performance of pebble-bed HTGRs under normal operation and accident conditions, including the pebble-bed reactor core as well as the primary loop, the helium blower, and the steam generator. Brief descriptions on the four modules are introduced in the 
TABLE 2: Parameters of protection system.

\begin{tabular}{lccc}
\hline Protection parameters & Triggering value & Triggering error & Delay time \\
\hline Neutron flux of full power level & $\geq 120 \%$ & $3 \%$ & $1 \mathrm{~s}$ \\
Neutron flux of middle power level & $\geq 200 \%$ & $6 \%$ & $1-30 \mathrm{~s}$ \\
Reactor period & $\leq 20 \mathrm{~s}$ & $10^{\circ} \mathrm{C}$ & $4^{\circ} \mathrm{C}$ \\
Temperature of hot helium & $\geq 790^{\circ} \mathrm{C}$ & $3 \%$ & $8 \mathrm{~s}$ \\
Temperature of cold helium & $\geq 345^{\circ} \mathrm{C}$ & $\leq 0.75 \mathrm{or} \geq 1.3$ & $0.053 \mathrm{MPa} / \mathrm{h}$ \\
Relative variation of the primary flow rate & $\geq .03 \mathrm{MPa} / \mathrm{min}$ & $3 \%$ & $1 \mathrm{~s}$ \\
Absolute sliding rate of the primary loop pressure & $\geq 25 \% / \mathrm{min}$ & & $1 \mathrm{~s}$ \\
Negative relative varying of the turbine power & &
\end{tabular}

following part and some detailed description of the equations used in the modules can be seen in [12].

2.1. Neutron Kinetics Module. Nuclear physical characteristics are predicted by a conventional point kinetics model with six groups of delayed neutrons in this module. Fission power is estimated through a balance of feedback reactivity and external reactivity. The former reactivity results from temperature variation of fuel, moderator, and reflector as well as change of xenon concentration, while the latter one is induced by movement of control rods or external inserted reactivity such as water ingress. In addition, decay heat is calculated by kinetic equations of the fission products.

2.2. Solid Heat Conduction Module. The conduction module includes a two-dimensional transient temperature model for solid materials and a one-dimensional transient temperature model for spherical fuel elements. Time-dependent general heat conduction equation is solved with temperaturedependent material properties in this module. In the simulation, a two-dimensional rotation symmetrical model in $r$, $z$ geometry is established for heat conduction of the HTR10GT. The computational model consists of 35 radial and 61 axial mesh points, as shown in Figure 2. It describes most of the HTR-10GT components such as pebble-bed core, graphite reflectors, carbon bricks, and reactor pressure vessel with 44 different material regions.

2.3. Gas Convection Module. A quasi-stationary gas flow model is used in the convection module to simulate the complex flow conditions inside a pebble-bed HTGR. This module solves steady-state continuity, momentum, and energy equations of gas in the reactor, coupled with a given timedependent temperature profile of solid structures. The computational model covers main flow passages in the HTR10GT, for example, reactor core, cold helium channels, cold and hot helium plenums, and control rod channels.

2.4. Primary Circuit Module. In this module, pressure, temperature, and mass flow rate of coolant in the primary loop are calculated. A quasi-stationary model, consisting of steadystate continuity, momentum, and energy equations of fluid, is used to predict the above-mentioned parameters. The calculating model of the HTR-10GT primary loop contains hot gas duct, power conversion unit in steam generator vessel, and so forth.

\section{Description of the Accidents}

All transients of the HTR-10GT, including DBA and BDBA, have been described in the "final safety analysis report" by the INET. Three typical accidents will be presented to illustrate the safety characteristics of the HTR-10GT in the following. In accident analyses, we always assume conservatively that the first scram signal fails to work. The protection system will scram the reactor when the second protective parameter reaches its limiting value.

The simulation study comprises three DBA cases of the HTR-10GT. The first one is induced by station blackout. Once a station blackout occurs, the helium blower and the steam turbine will shut down immediately, leading to a loss of coolant flow and a decrease of heat exchange from the primary loop. As the core continues to be heated up, the fuel temperature will rise and the pressure and temperature in the primary loop will increase, too. The core power declines due to negative temperature feedback. As soon as the offsite power is lost, the control rods drop automatically by gravity. On the other hand, the protection system would detect a scram signal when the pressure, the flow rate of the primary loop, or the turbine power reaches specified values.

The second case is induced by a control rod withdrawal out of core by mistake. The positive reactivity inserted is determined by location of the control rod in the reflectors and operating state. The performed analysis is for typical operating conditions with full rated power of an equilibrium core and with reactivity of a control rod less than $1 \%$. The total reactivity inserted by a control rod withdrawal is shown in Figure 3. In this case, the protection system receives three scram signals: too high neutron flux in the relative power level referenced to the rated power $(\geq 1.23)$, too high helium temperature at core outlet $\left(\geq 800^{\circ} \mathrm{C}\right)$, and too large absolute sliding rate of the primary system pressure $(\geq 0.031 \mathrm{MPa} / \mathrm{min})$.

The last case calculated is caused by earthquake. When an earthquake occurs in the HTR-10GT, the compactness of the pebble bed will increase due to violent shaking, which will lead to a decreasing neutron leakage rate. There is also a relative shift between the top of the active core and the control rods in the reflectors. This results in a positive 


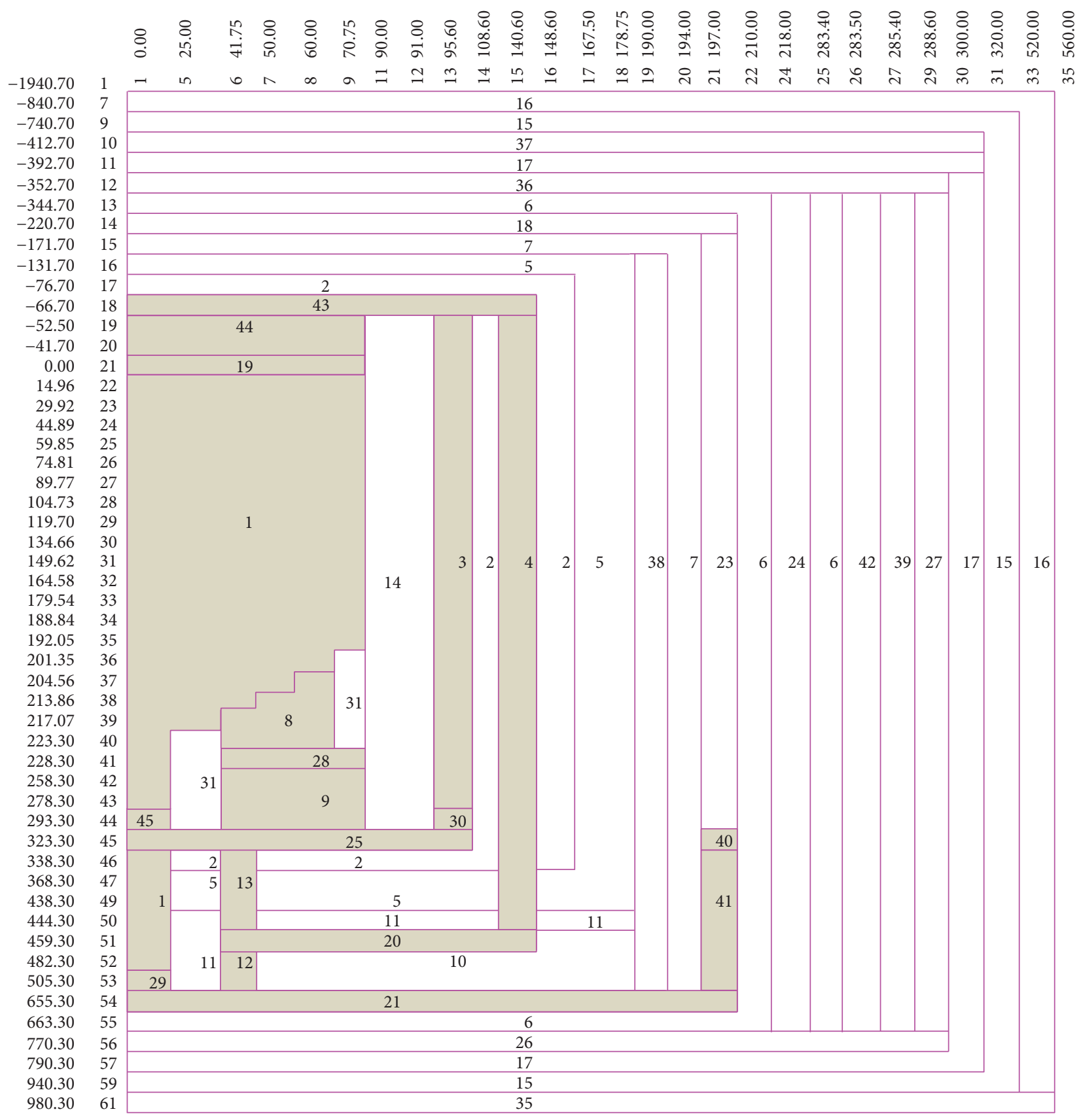

FIGURE 2: THERMIX model of the HTR-10GT core. 1, core; 2, 14, and 31, side reflectors without channels; 3 , side reflectors within control rod channels; 4, side reflectors within cooling channels; 5, carbon brick; 6, reactor pressure vessel; 7, core shell; 8, top part of the bottom reflector within flow channels; 9, lower part of the bottom reflector within flow channels; 10 and 11, steel support in the core bottom; 12 , annulus passage of cold helium at the core bottom; 13, leakage inside the metal internals; 15 , concrete; 16, side boundary of flow; 17, thermal insulation; 18, top helium cavity in the RPV; 19, core inlet cavity; 20, flow passages around the core bottom; 21, bottom helium cavity in RPV; 23, helium gap between the RPV and the core shell; 24, side air cavity outside the RPV; 25 , outlet cavity at the core bottom; 26 , bottom air cavity outside the RPV; 27, side part of the reactor cavity; 28, cavity inside the bottom reflectors; 29, inlet throttle of the refueling pipe; 30 , outlet throttle of control rod channels; 35 , bottom boundary of flow; 36 , top air cavity outside the RPV; 37, air cavity in the top of the reactor cavity; 38 , side helium gap inside the core shell; 39, cavity cooling system; 40, helium inlet channel in the core shell; 41, annular flow passage inside the core shell; 42 , air gap outside the thermal insulation of the reactor cavity; 43 , helium cavity in the top reflectors; 44 , helium passage in the top reflectors. 


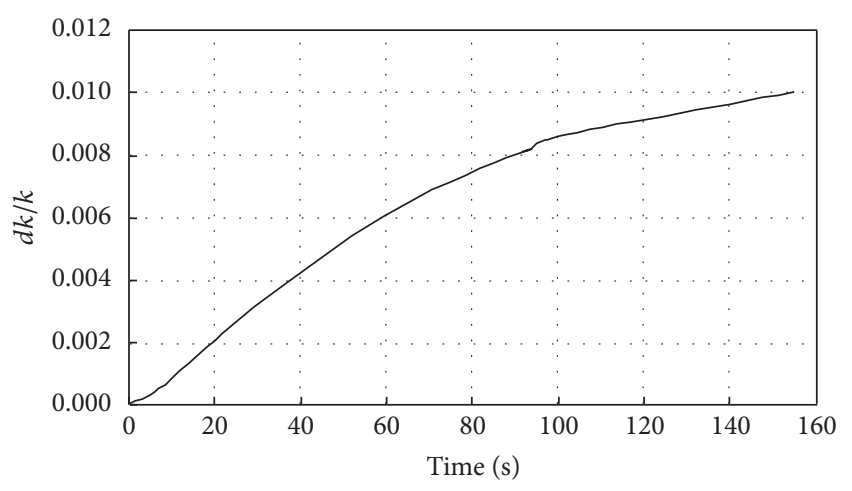

FIGURE 3: Reactivity inserted by a control rod withdrawal.

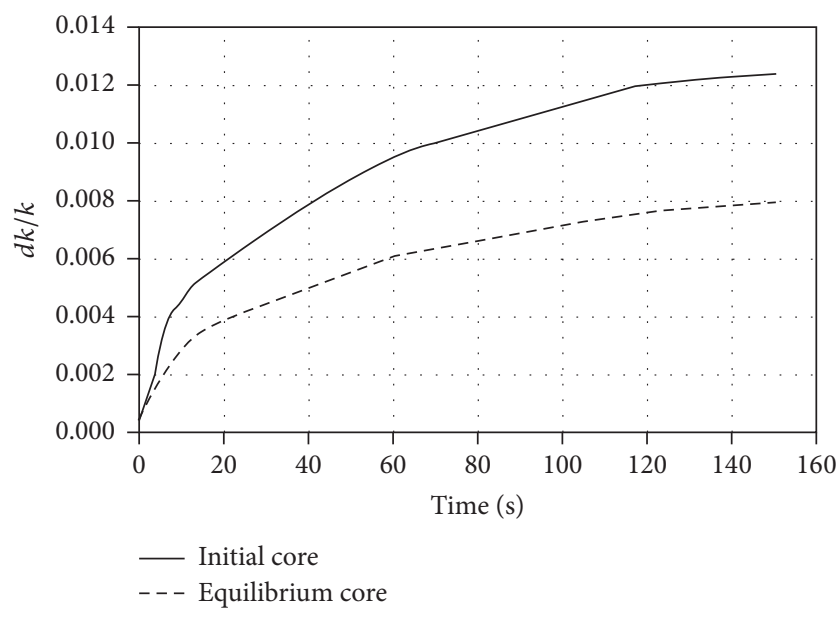

FIGURE 4: Reactivity inserted by an earthquake.

reactivity insertion. The horizontal acceleration at the surface of the earth induced by an earthquake is $2.0 \mathrm{~m} / \mathrm{s}^{2}$ during normal operation. The shaking experiments on pebble beds in Germany showed that horizontal forces caused by an earthquake would result in a densification of the pebblebed core, reaching a peak after 3 4 minutes as earthquake forces continue. The initial packing fraction of a randomly composed pebble-bed core is 0.61 . If the surface horizontal acceleration increases from $2.0 \mathrm{~m} / \mathrm{s}^{2}$ to $10 \mathrm{~m} / \mathrm{s}^{2}$, the peak packing fraction of the bed increases from 0.615 to 0.64 , as specified in the HTR-10 final safety analysis report. In our analysis, a conservative hypothesis is taken demonstrating that the packing fraction of the HTR-10GT core increases during the earthquake from 0.61 to 0.64 -the maximum value attainable in a random packing of spheres. The total reactivity inserted by an earthquake is $1.24 \%$ and $0.788 \%$, calculated by VSOP, for an initial core and an equilibrium core, respectively, which can be seen in Figure 4. The timedependent variation of reactivity in the plot will be used in the analysis. After an earthquake, the HTR-10GT protection system will receive two scram signals: too high neutron flux in relative power level referenced to the rated power $(\geqslant 1.23)$ and too short reactor period $(\leqslant 20 \mathrm{~s})$.

The accident detection and protection system of the HTR10GT is triggered by scram signals. As mentioned above, the first scram signal is assumed to be skipped in the analysis. After the second scram signal, the protection system takes actions to shut down the reactor, which include dropping the control rods into the reflectors by gravity, shutting down the primary circuit blower, stopping the gas turbine, and isolating the primary circuit. The accidents mentioned above are classified to level II accidents [8], which may happen once a year, and the reactor can restore normal operation after shutdown and taking some measures. During these accidents, the reactor can scram and residual decay heat will be removed from the reactor vessel by the reactor cavity cooling system through heat transfer in form of conduction, convection, and radiation among in-vessel structures and the core.

\section{Hypothesis and Calculating Conditions}

The spherical fuel elements containing coated TRISO particles can effectively retain all relevant radioactive fission products up to the temperature of $1620^{\circ} \mathrm{C}$. In the first phase of the HTR-10 project, the coated particle fuel was experimentally proven to keep its integrity and retain the radioactive fission products effectively up to $1250^{\circ} \mathrm{C}$. So the maximum temperature of fuel elements is set as $1230^{\circ} \mathrm{C}$ under all accident conditions for HTR-10. For the HTR-10GT, the peak fuel temperature permitted in accidents is set to be $1230^{\circ} \mathrm{C}$ in the beginning. After more tests on spherical fuel elements, the setting point of fuel peak temperature in accidents is increased to $1620^{\circ} \mathrm{C}$, which is used in the HTRPM and the second phase of the HTR-10GT designing.

The study analyses typical operating cases of the HTR10GT in full power for the three accidents consequences. The assumed conditions when the accidents occur are the following:

(i) The core operating power is the rated power with an addition of $5 \%$ due to measuring error.

(ii) The cooling flow passing through the core is $86 \%$ of the rated pump flow.

(iii) The core is in an equilibrium state and the total reactivity inserted by a control rod withdrawal is $1 \%$.

(iv) One control rod in the reflector is drawn up at a speed of $1 \mathrm{~cm} / \mathrm{s}$.

(v) The first scram signal is skipped and the protecting system takes actions following the second signal.

(vi) The worst effect of instruments measuring error is considered when scram signals are triggered.

(vii) Longest time delay before the protecting measures action is considered.

(viii) When the reactor scrams, the flow rate in the primary loop decreases to $0.0 \mathrm{~kg} / \mathrm{s}$ in 0.25 seconds and the gas turbine is bypassed in $0.25 \mathrm{~s}$ (which is an extremely conservative condition).

\section{Computational Results}

For the HTR-10GT, the initial core and the equilibrium core have different physical characteristics. In fact, there is no truly 
TABLE 3: Accident sequence of an initial core induced by station blackout.

\begin{tabular}{lcc}
\hline Events & $\begin{array}{c}\text { HTR- } \\
10 \mathrm{GT}\end{array}$ & HTR-10 \\
\hline $\begin{array}{l}\text { Station blackout occurs, helium blower and } \\
\text { turbine shut down }\end{array}$ & $0.0 \mathrm{~s}$ & $0.0 \mathrm{~s}$ \\
$\begin{array}{l}\text { Absolute sliding rate of the turbine power } \geqslant \\
\text { 28\%/min }\end{array}$ & 20.0 & 20.0 \\
$\begin{array}{l}\text { Absolute sliding rate of the system pressure } \\
\geqslant 0.031 \mathrm{MPa} / \mathrm{min}\end{array}$ & $38.2 \mathrm{~s}$ & $35.8 \mathrm{~s}$ \\
$\begin{array}{l}\text { Protection system takes actions to scram } \\
\text { Time at which fuel temperature reaches a }\end{array}$ & $39.2 \mathrm{~s}$ & $36.8 \mathrm{~s}$ \\
$\begin{array}{l}\text { peak } \\
\text { Peak fuel temperature }\end{array}$ & $0.0 \mathrm{~s}$ \\
$\begin{array}{l}\text { Time at which system pressure reaches a } \\
\text { peak }\end{array}$ & $1066^{\circ} \mathrm{C}$ & $1033^{\circ} \mathrm{C}$ \\
\begin{tabular}{l} 
Peak system pressure \\
\hline
\end{tabular} & $78.8 \mathrm{~s}$ \\
\hline
\end{tabular}

TABle 4: Accident sequence of an equilibrium core induced by station blackout.

\begin{tabular}{lcc}
\hline Events & $\begin{array}{c}\text { HTR- } \\
10 \mathrm{GT}\end{array}$ & HTR-10 \\
\hline $\begin{array}{l}\text { Station blackout occurs, the helium blower } \\
\text { and turbine shut down }\end{array}$ & $0.0 \mathrm{~s}$ & $0.0 \mathrm{~s}$ \\
$\begin{array}{l}\text { Absolute sliding rate of the turbine power } \geqslant \\
28 \% / \text { min }\end{array}$ & $20.0 \mathrm{~s}$ & $20.0 \mathrm{~s}$ \\
$\begin{array}{l}\text { Absolute sliding rate of system pressure } \geqslant \\
\begin{array}{l}\text { 0.031 MPa/min } \\
\text { Protection system takes actions to scram }\end{array}\end{array}$ & $66.9 \mathrm{~s}$ & $36.0 \mathrm{~s}$ \\
$\begin{array}{l}\text { Time at which fuel temperature reached a } \\
\text { peak }\end{array}$ & $68.0 \mathrm{~s}$ & $0.0 \mathrm{~s}$ \\
$\begin{array}{l}\text { Peak fuel temperature } \\
\text { Time at which system pressure reached a } \\
\text { peak }\end{array}$ & 989.0 & $944^{\circ} \mathrm{C}$ \\
Peak system pressure & $15.2 \mathrm{~s}$ & $78.7 \mathrm{~s}$ \\
\hline
\end{tabular}

initial core for the HTR-10GT, as the HTR-10 will have been operating for years. However, the three cases studied here are based on an initial core similar to that of the HTR-10 in order to better compare the accident consequences. Of course, the cases for an equilibrium core were simulated, too.

5.1. Accident Induced by Station Blackout. Tables 3 and 4 indicate the key events following a station blackout of the HTR-10GT. The accident consequences of the HTR-10 induced by station blackout are compared in Tables 3 and 4, too. Figures 5-10 show the plots of important parameters of HTR-10GT in accident for both the startup core and the equilibrium core, which consist of reactor power, peak fuel temperature, average fuel temperature, temperature feedback reactivity, total reactivity, and primary system pressure.

Once a station blackout occurs, the helium blower and the gas turbine would shut down quickly. 20 seconds later, the first scram signal "absolute sliding rate of the turbine power" reaches its setting value of $28 \% / \mathrm{min}$, but it is skipped.

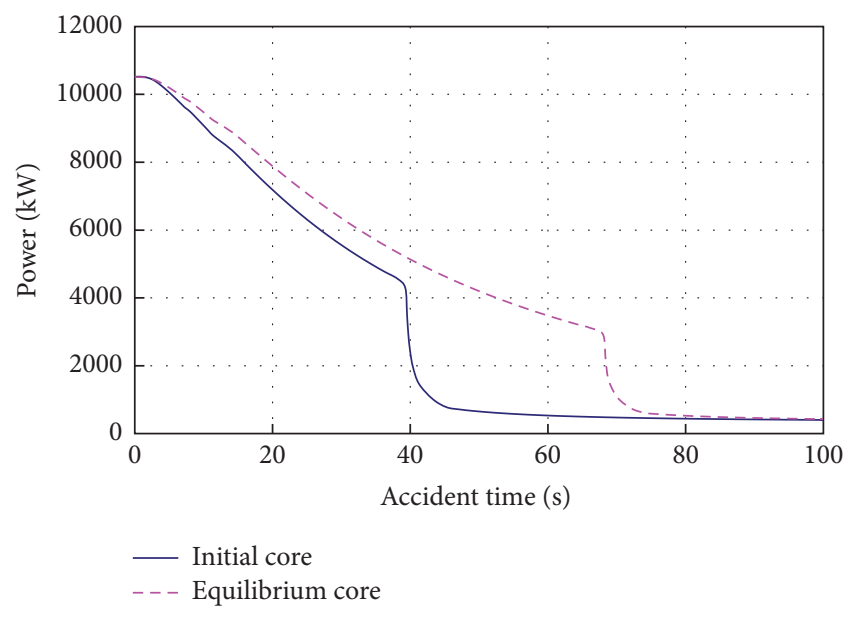

FIGURE 5: Power in station blackout accident of the HTR-10GT.

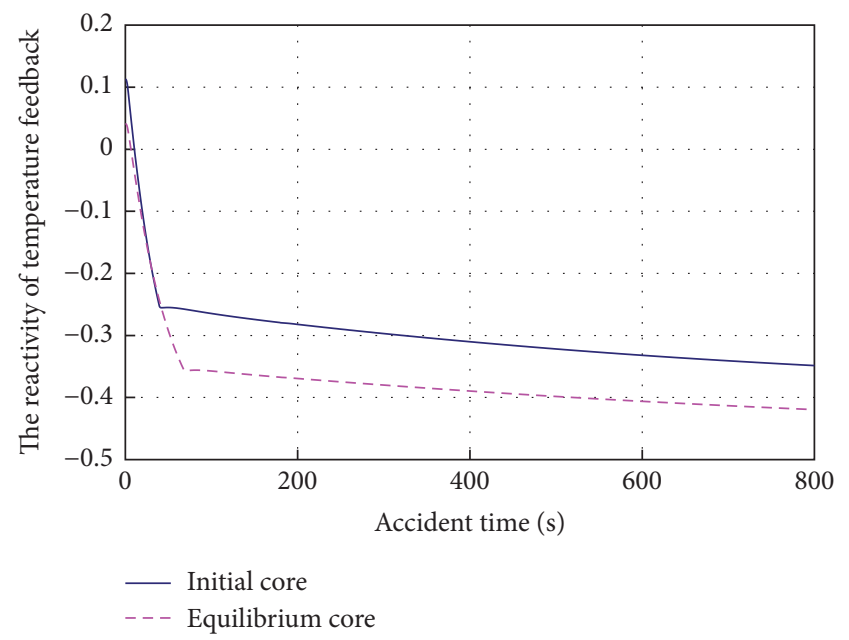

FIGURE 6: Temperature feedback reactivity in station blackout accident of the HTR-10GT.

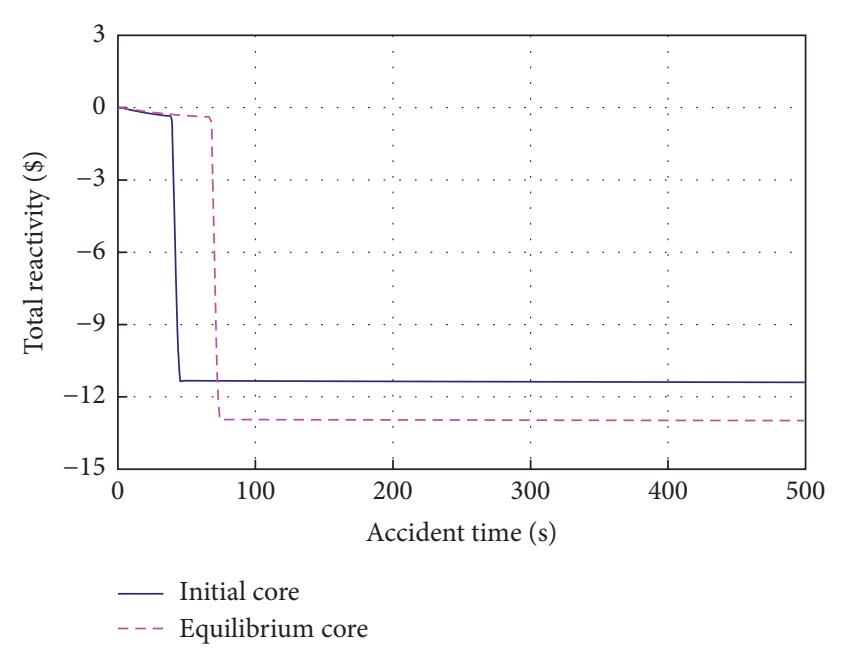

FIGURE 7: Total reactivity in station blackout accident of the HTR10GT. 


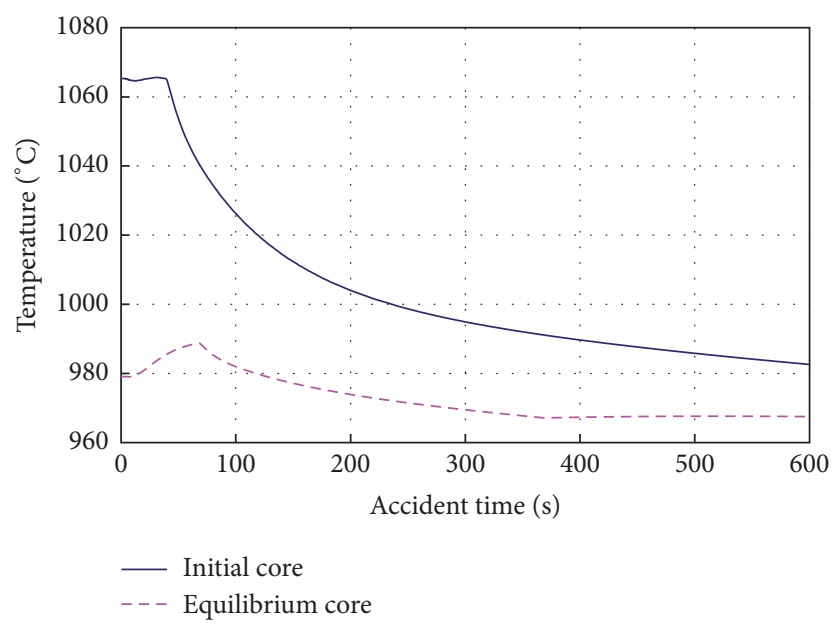

FIGURE 8: Peak fuel temperature in station blackout accident of the HTR-10GT.

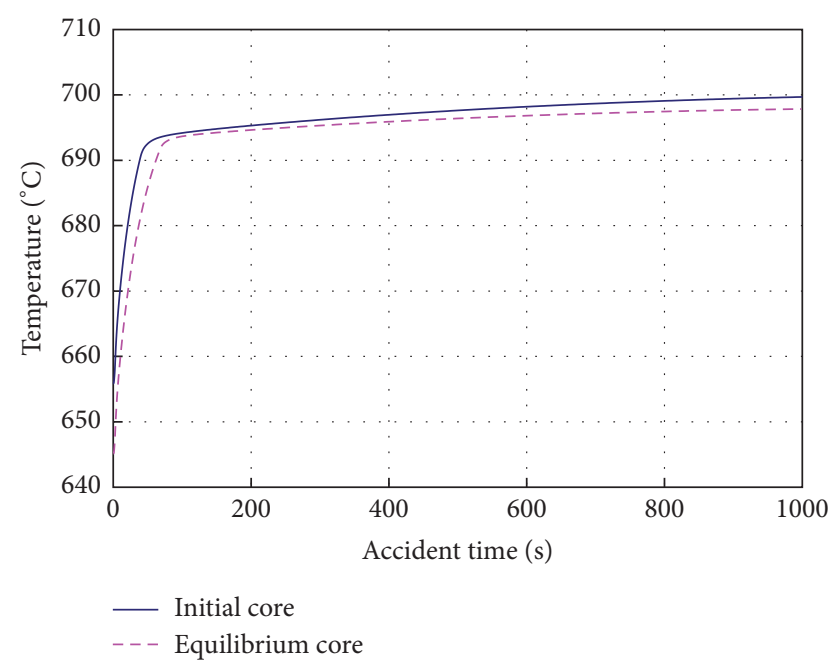

FIGURE 9: Fuel average temperature in station blackout accident of the HTR-10GT.

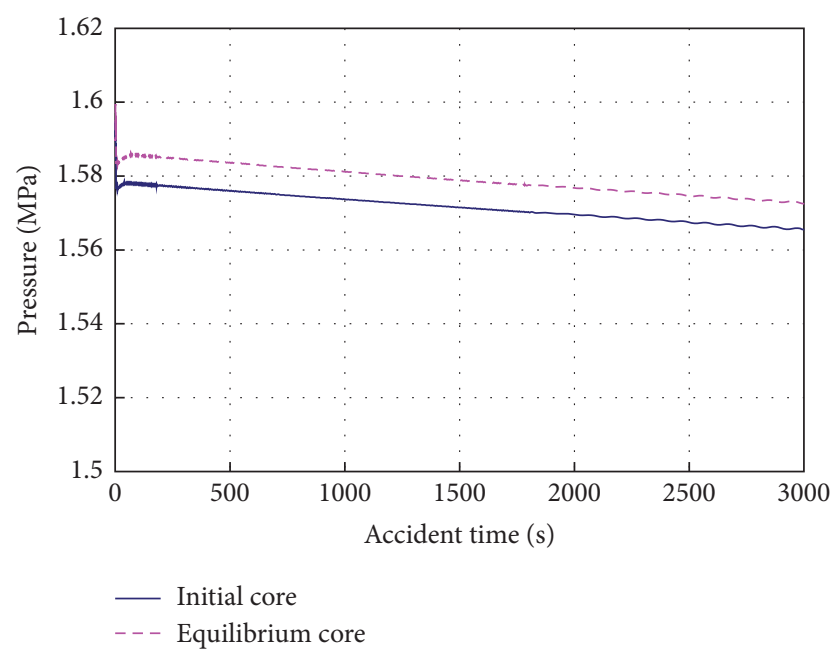

FIGURE 10: System pressure in station blackout accident of the HTR10GT.
TABLE 5: Accident sequence of an initial core induced by a control rod withdrawal by mistake.

\begin{tabular}{lcc}
\hline Events & HTR-10GT & HTR-10 \\
\hline $\begin{array}{l}\text { A control rod begins to } \\
\text { withdraw out of the reflectors } \\
\text { at a speed of } 1 \mathrm{~cm} / \mathrm{s}\end{array}$ & $0.0 \mathrm{~s}$ & $0.0 \mathrm{~s}$ \\
$\begin{array}{l}\text { Neutron flux of power level } \\
\geqslant 1.23\end{array}$ & $8.85 \mathrm{~s}$ & $11.3 \mathrm{~s}$ \\
$\begin{array}{l}\text { Core power reaches a peak } \\
\text { Hot helium temperature }\end{array}$ & $37.8 \mathrm{~s}(24.3 \mathrm{MW})$ & $\begin{array}{c}36.4 \mathrm{~s} \\
(23.5 \mathrm{MW})\end{array}$ \\
$\begin{array}{l}\text { exceeds its setting point } \\
\begin{array}{l}\text { Time at which control rods } \\
\text { begin to drop }\end{array}\end{array}$ & $80.1 \mathrm{~s}\left(800^{\circ} \mathrm{C}\right)$ & $84.9 \mathrm{~s}\left(750^{\circ} \mathrm{C}\right)$ \\
$\begin{array}{l}\text { Fuel temperature reaches a } \\
\text { peak }\end{array}$ & $83.5 \mathrm{~s}\left(1201^{\circ} \mathrm{C}\right)$ & $93.3 \mathrm{~s}\left(1170^{\circ} \mathrm{C}\right)$ \\
$\begin{array}{l}\text { Time at which the accident } \\
\text { rod is withdrawn out of the } \\
\text { reflectors }\end{array}$ & & \\
\hline
\end{tabular}

The second signal is detected after $38.2 \mathrm{~s}$ and $66.9 \mathrm{~s}$ for the initial core and the equilibrium core, respectively. Then the protection system takes actions to scram and the HTR-10GT shuts down immediately. The peak fuel temperature in the accident is calculated to be $1066^{\circ} \mathrm{C}$ and $989^{\circ} \mathrm{C}$ for the startup core and the equilibrium core, respectively. For the HTR-10, the corresponding temperatures are $1033^{\circ} \mathrm{C}$ and $944^{\circ} \mathrm{C}$. The peak fuel temperature of the HTR-10GT is about $45^{\circ} \mathrm{C}$ higher than that of the HTR-10. The difference between the peak fuel temperatures of the HTR-10GT and HTR-10 is consistent with the difference in the steady-state core outlet temperatures.

From Table 3, we can see that the second scram signal "absolute sliding rate of the system pressure" of the HTR10GT reaches its setting value later than the HTR-10. This is due to the fact that the system pressure of the HTR10GT is lower than the HTR-10. Figure 10 shows a plot of the transient system pressures during the accident. From the corresponding plots of the temperature feedback reactivity and the total reactivity in Figures 6 and 7, one can see that the second signal is detected much later for an equilibrium core than an initial core. The shutdown in an initial core takes place earlier and its power decreases more quickly than in an equilibrium core, as shown in Figure 5. Figures 8 and 9 depict the peak and average fuel temperatures. As the peak fuel temperature is lower than $1230^{\circ} \mathrm{C}$, it can be concluded that the HTR-10GT remains in a safe condition in a station blackout accident scenario.

5.2. Accident Induced by a Control Rod Withdrawal out of the Reflectors. Tables 5 and 6 show the important events since a control rod is withdrawn out of the reflectors at a speed of $1 \mathrm{~cm} / \mathrm{s}$ by mistake. The accident consequences of the HTR-10 are also compared in Tables 5 and 6. Figures 11-18 depict plots of important parameters of the HTR10GT in accident for both an initial core and an equilibrium core, which consist of reactor power, peak fuel temperature, average fuel temperature, temperature feedback reactivity, 
TABLE 6: Accident sequence of an equilibrium core induced by a control rod withdrawal by mistake.

\begin{tabular}{lcc}
\hline Events & HTR-10GT & HTR-10 \\
\hline $\begin{array}{l}\text { A control rod begins to } \\
\text { withdraw out of the reflectors } \\
\text { at a speed of } 1 \mathrm{~cm} / \mathrm{s}\end{array}$ & $0.0 \mathrm{~s}$ & $0.0 \mathrm{~s}$ \\
$\begin{array}{l}\text { Neutron flux of power level } \\
\geqslant\end{array}$ & $10.5 \mathrm{~s}$ & $10.5 \mathrm{~s}$ \\
$\begin{array}{l}\text { Core power reaches a peak } \\
\text { Hot helium temperature }\end{array}$ & $39.4 \mathrm{~s}(31.1 \mathrm{MW})$ & $37.9 \mathrm{~s}(30.3 \mathrm{MW})$ \\
$\begin{array}{l}\text { exceeds its setting point } \\
\text { Time at which control rods } \\
\text { begin to drop }\end{array}$ & $54.9 \mathrm{~s}\left(800^{\circ} \mathrm{C}\right)$ & $54.9 \mathrm{~s}\left(750^{\circ} \mathrm{C}\right)$ \\
$\begin{array}{l}\text { Fuel temperature reaches a } \\
\text { peak }\end{array}$ & $55.7 \mathrm{~s}\left(1066^{\circ} \mathrm{C}\right)$ & $64.0 \mathrm{~s}\left(1041^{\circ} \mathrm{C}\right)$ \\
$\begin{array}{l}\text { Time at which the accident } \\
\text { rod is withdrawn out of the } \\
\text { reflectors }\end{array}$ & $155.0 \mathrm{~s}$ & $155.0 \mathrm{~s}$ \\
\hline
\end{tabular}

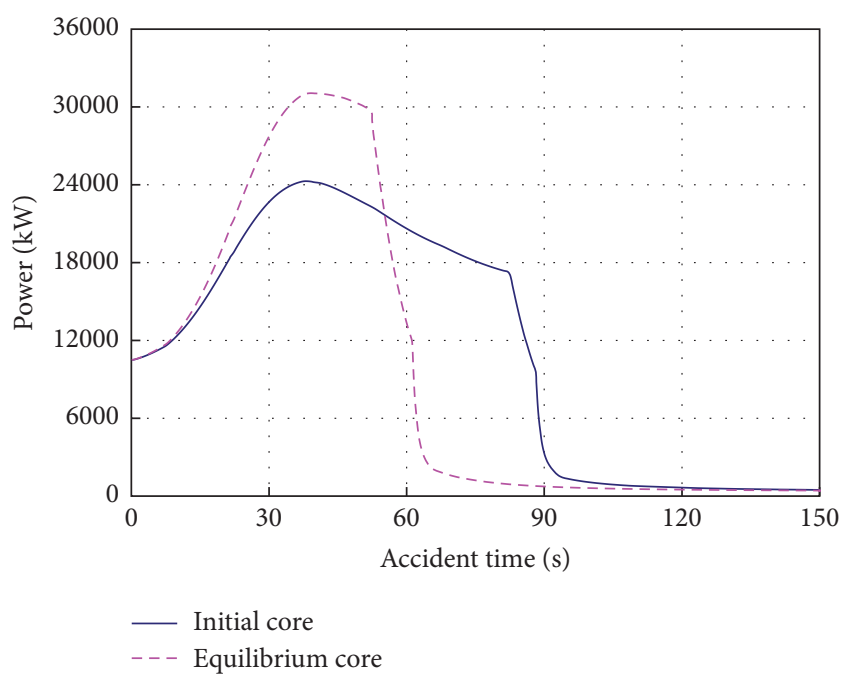

FIGURE 11: Core power in a control rod withdrawal accident of the HTR-10GT.

total reactivity, flow rate of primary loop, system pressure, and helium temperature at core inlet and outlet.

When a control rod is withdrawn out of the reflectors in 155 seconds by mistake, core power increases quickly due to a positive reactivity inserted. The reactivity worth of one control rod of the HTR-10GR is shown in Figure 3, which is larger than that of the HTR-10. As core power increases, the first scram signal triggered by high flux is ignored in the simulation. The second signal triggered by high helium temperature occurs about half a minute later. Then all control rods begin to drop due to the shutting down actions taken by the protection system, which leads to the HTR-10GT shutting down safely.

From Table 5, we can see that neutron flux of the HTR10GT core increases more quickly than that of the HTR10 , because the absolute value of its feedback coefficient of reactivity caused by temperature change becomes smaller as

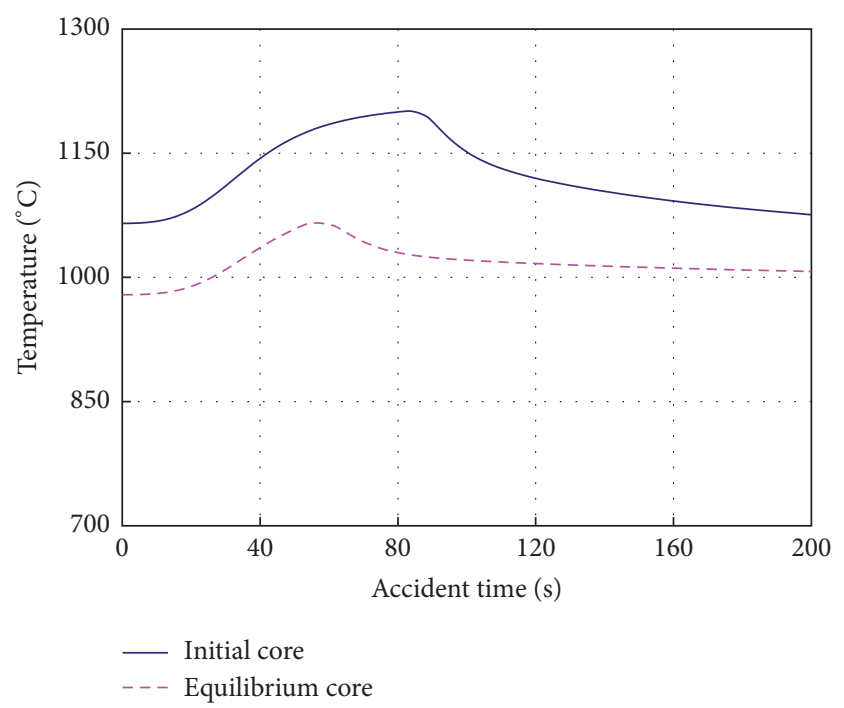

Figure 12: Peak fuel temperature in a control rod withdrawal accident of the HTR-10GT.

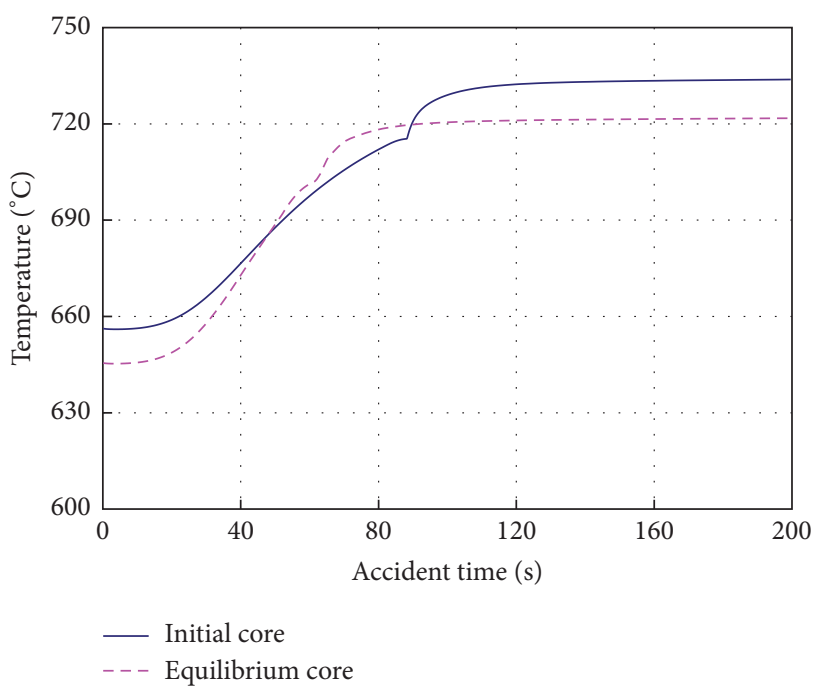

FIGURE 13: Fuel average temperature in a control rod withdrawal accident of the HTR-10GT.

the core operating temperature increases. Thus, for the HTR10GT, the power increases rapidly and the peak power is higher, which leads to an earlier scram signal for the second time. The peak fuel temperature increases in the accident by about $30^{\circ} \mathrm{C}$, which is smaller than $50^{\circ} \mathrm{C}$-the helium temperature increased at the core outlet.

The plot in Figure 11 shows that the power of an initial core in accident increases slower than an equilibrium core, so the peak power is lower, which results in a higher peak fuel temperature. This is due to the fact that the initial core has a small value of absolute temperature reactivity feedback coefficient, as shown in Figure 17. One can also see in Figure 12 that the initial core of the HTR-10GT has a higher peak of fuel temperature, while the equilibrium core has a higher average temperature of fuel, as shown in Figure 13. This 


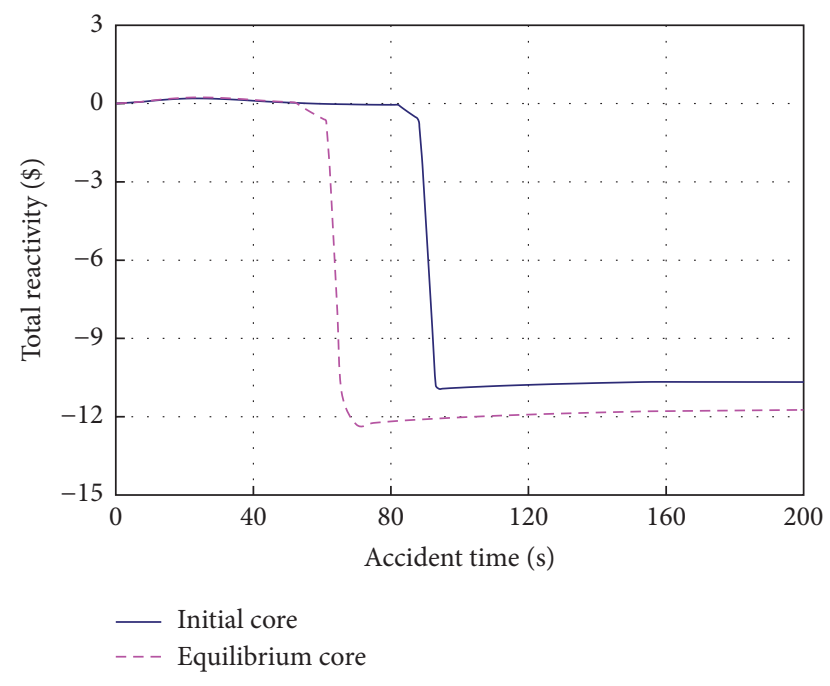

FIGURE 14: Total reactivity in a control rod withdrawal accident of the HTR-10GT.

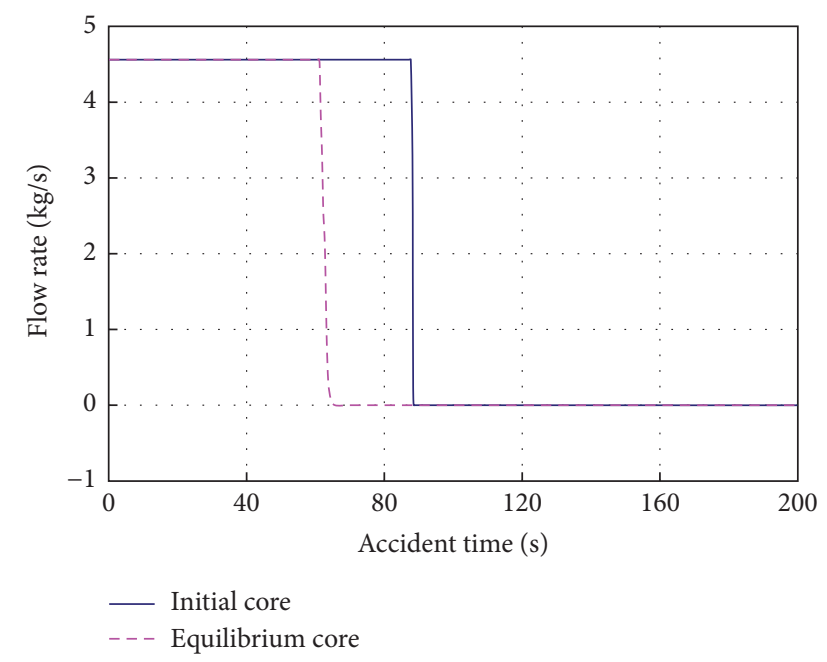

FIGURE 15: Flow rate of the primary loop in a control rod withdrawal accident of the HTR-10GT.

is also a result of the reactivity characteristics of the HTR$10 \mathrm{GT}$ core. Figure 16 shows the helium temperature at the core inlet and outlet.

When the second scram signal is detected, the protection system takes shutdown actions. Dropping control rods leads total reactivity to decrease quickly, as shown in Figure 14. In Figure 15, we can see that isolating the primary loop makes the helium flow in it nearly stop. The curves in Figure 18 show that the system pressure remains almost unchanged for both cores during the accident. The peak fuel temperature in accident is calculated to be $1201^{\circ} \mathrm{C}$ and $1066^{\circ} \mathrm{C}$ for the initial core and the equilibrium core, respectively, while for the HTR10 the temperatures are $1170^{\circ} \mathrm{C}$ and $1041^{\circ} \mathrm{C}$, respectively. The peak fuel temperature of the HTR-10GT is higher than that of the HTR-10, but both are lower than $1230^{\circ} \mathrm{C}$. The HTR10GT remains in safe conditions in a control rod withdrawal accident scenario [13-15].

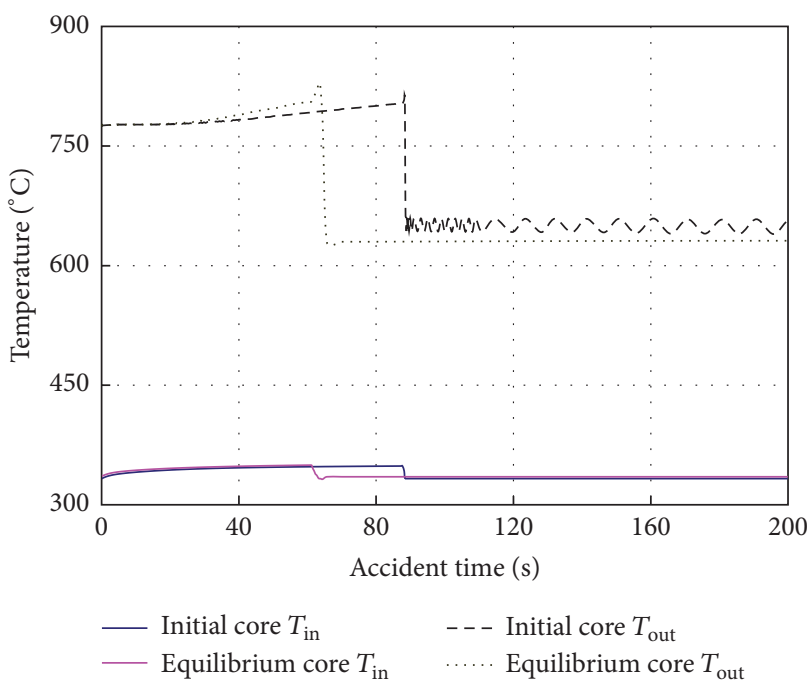

FIGURE 16: Core helium temperature in a control rod withdrawal accident of the HTR-10GT.

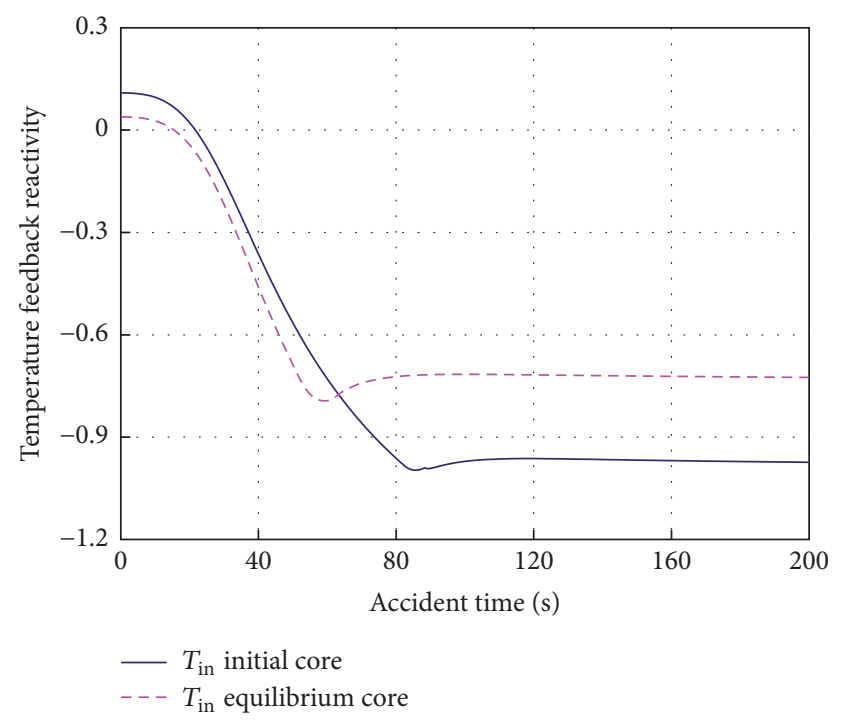

FIGURE 17: Temperature feedback reactivity in a control rod withdrawal accident of the HTR-10GT.

5.3. Accident Induced by Earthquake. Tables 7 and 8 depict the important events in the HTR-10GT following an earthquake. The accident consequences of the HTR-10 are also compared in Tables 7 and 8. Figures 19-26 show the plots of key parameters of the HTR-10GT in accident for both an initial core and an equilibrium core, which consist of reactor power, peak fuel temperature, average fuel temperature, temperature feedback reactivity, total reactivity, flow rate of primary loop, system pressure, and helium temperatures at core inlet and outlet.

In less than 150 seconds after an earthquake occurs, a total reactivity of $1.24 \%$ is inserted into the startup up core and $0.788 \%$ is inserted into the equilibrium core. Core power begins to go up as soon as the positive reactivity insertion starts. Then the core temperature increases and the reactor 


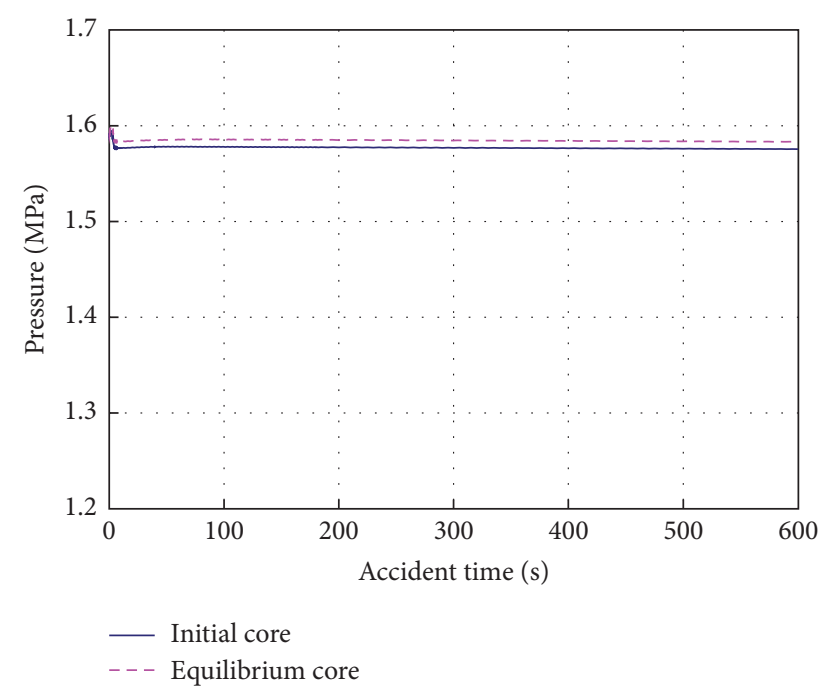

FIGURE 18: System pressure in a control rod withdrawal accident of the HTR-10GT.

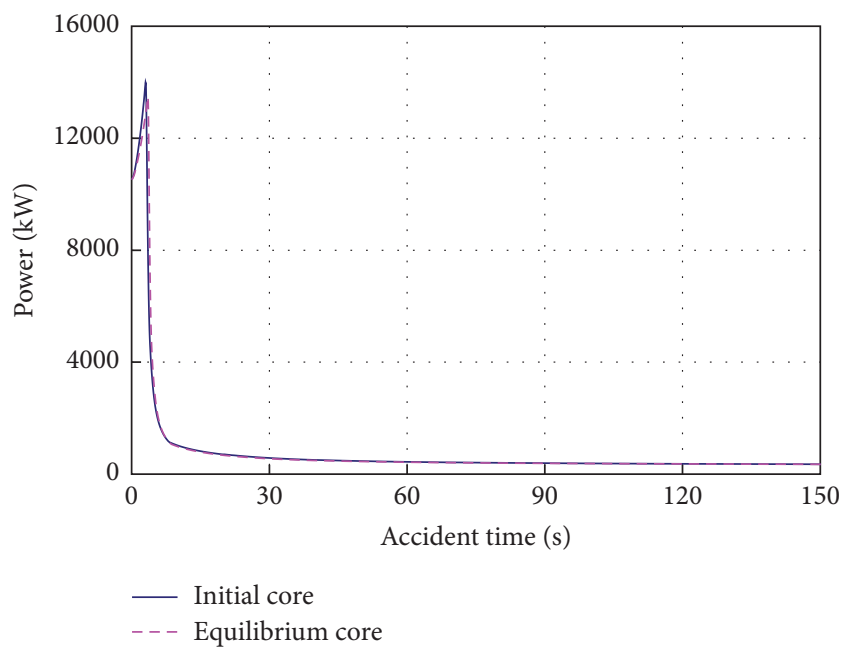

FIGURE 19: Core power in an earthquake accident of the HTR-10GT.

will shut down by itself due to negative temperature reactivity feedback, even though there is no shutdown action. The first scram signal triggered by a short period measurement is soon received but is ignored as assumed. Two seconds later, the second signal (high flux) is detected and the protection system scrams the reactor. The peak fuel temperatures in the accident are $1067^{\circ} \mathrm{C}$ and $980^{\circ} \mathrm{C}$ for the initial core and the equilibrium core, respectively, while for HTR-10 the temperatures are $1038^{\circ} \mathrm{C}$ and $945^{\circ} \mathrm{C}$, respectively. The peak fuel temperature of HTR-10GT in accident is about $30^{\circ} \mathrm{C}$ higher than that of HTR-10. Shortly afterwards, the HTR10GT reactor shuts down safely. Both fuel peak temperatures are lower than $1230^{\circ} \mathrm{C}$. The HTR-10GT remains in a safe condition in an earthquake accident scenario.

Tables 7 and 8 tell us that the earthquake accident consequences in the HTR-10GT progress more quickly than in the HTR-10, because the HTR-10GT operates at a higher

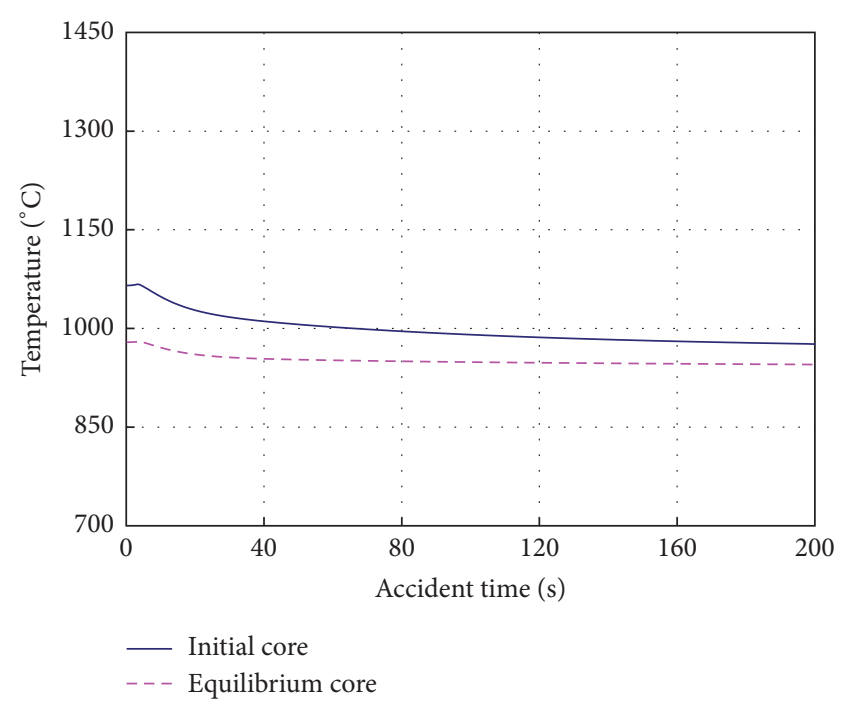

FIGURE 20: Fuel peak temperature in an earthquake accident of the HTR-10GT.

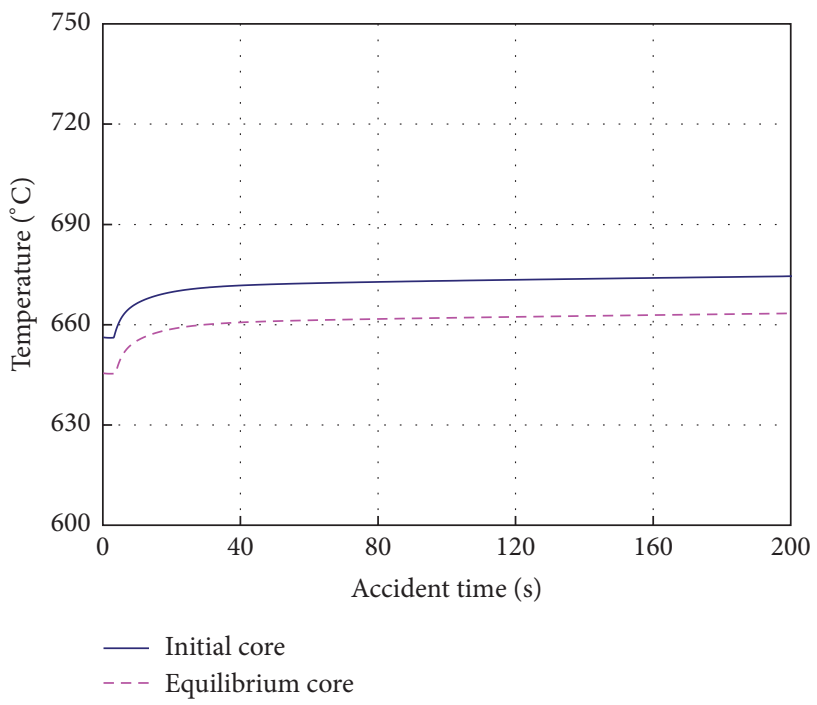

FIGURE 21: Average fuel temperature in an earthquake accident of the HTR-10GT.

temperature and it has a faster temperature feedback. The peak fuel temperature of the HTR-10GT is higher than that of HTR-10, which leads to a fast reactivity feedback that causes the peak power of HTR-10GT less than that of HTR-10. The peak fuel temperature increase in the accident is about $30^{\circ} \mathrm{C}$, which is lower than $50^{\circ} \mathrm{C}$-the helium temperature increased at core outlet.

Comparing Figures 11 and 19, one can find that the core power increases more quickly in the earthquake accident than in the control rod withdrawal case for different positive insertion speeds. Because of the temperature negative feedback of reactivity, the peak and average fuel temperatures only rise a little as shown in Figures 20 and 21. Total reactivity plotted in Figure 22 and temperature feedback reactivity plotted in Figure 25 illustrate a relatively short time to reach 


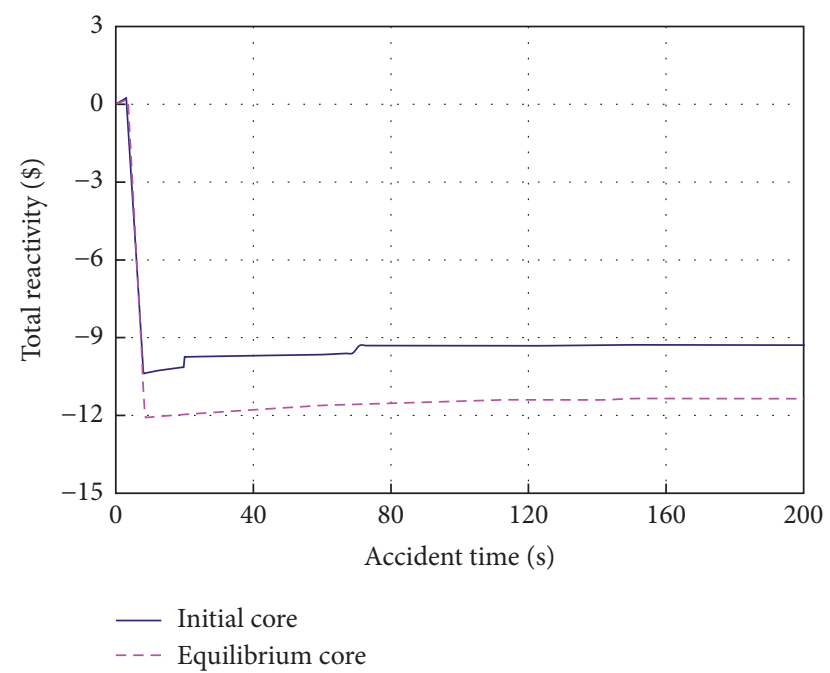

FIGURE 22: Total reactivity in an earthquake accident of the HTR10GT.

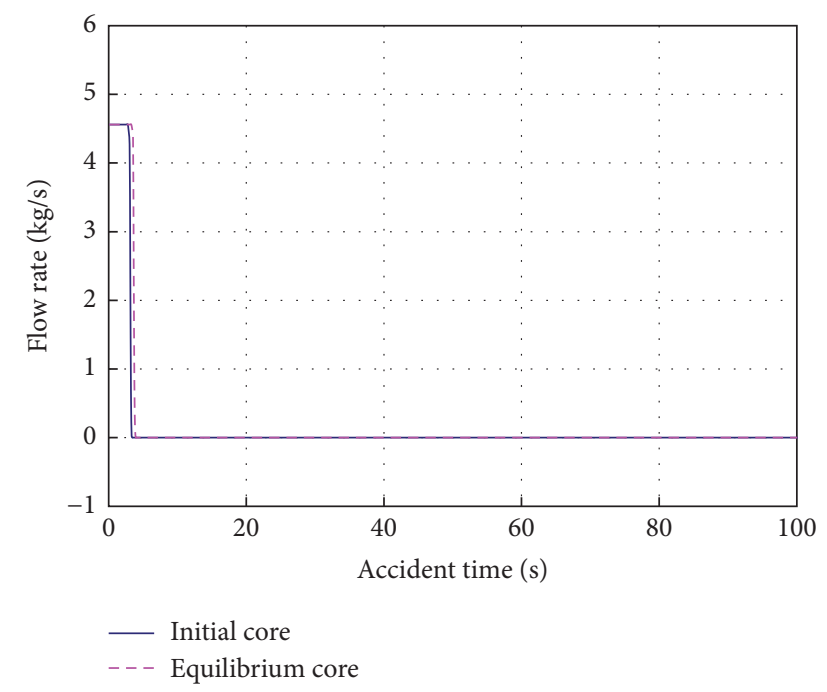

FIGURE 23: Flow rate of primary loop in an earthquake accident of the HTR-10GT.

peaks of power and temperature. One can also see that in the earthquake accident the flow rate in the primary loop as shown in Figure 23 and the helium temperature of core as plotted in Figure 24 proceed smoothly. In the scram, the system remains in a high pressure condition, which can be seen in Figure 26, and it shows a similar behavior to that in a control rod withdrawal accident. In an earthquake accident, protection system takes measures to scram and leads to safe shutting down, which is similar to a control rod withdrawal accident.

\section{Conclusions}

The HTR-10GT is the second phase of HTGR technology development in China. It is based upon the reactor core of HTR-10 and replaces the steam generator with a helium

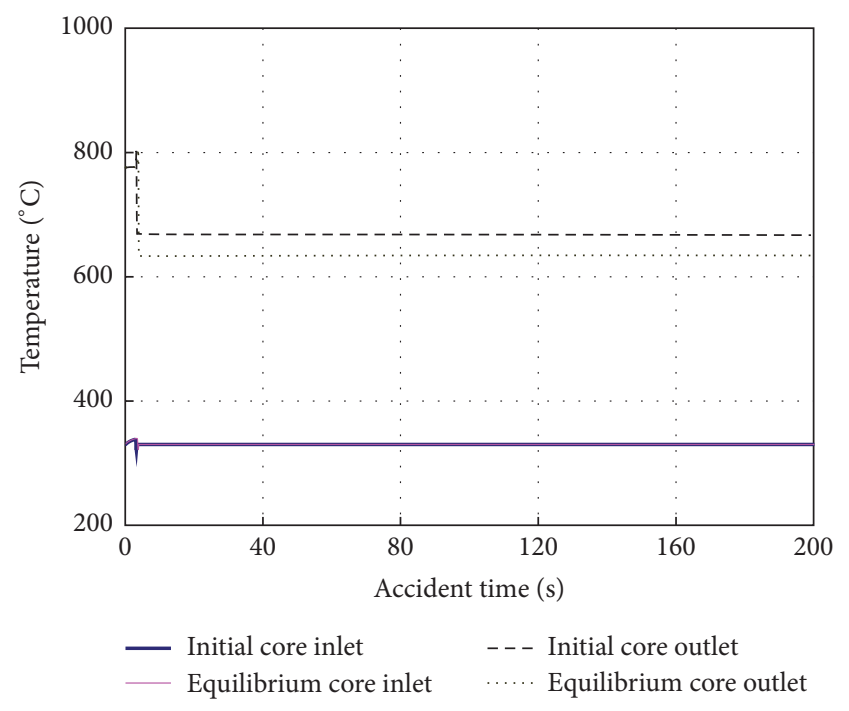

FIgURE 24: Temperature of core helium in an earthquake accident of the HTR-10GT.

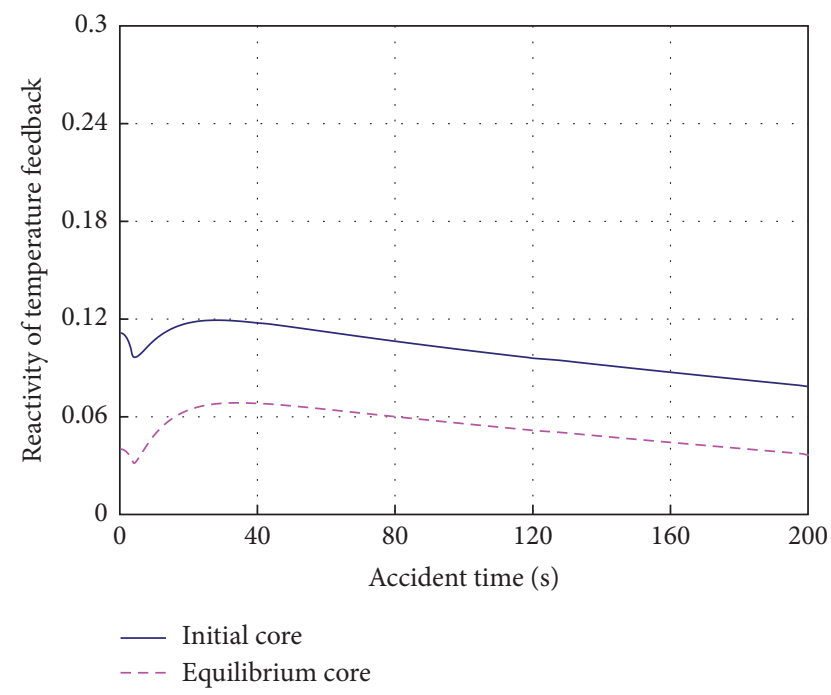

FIgURE 25: Temperature feedback reactivity in an earthquake accident of the HTR-10GT.

turbine generator. Although its physical core remains the same as HTR-10, the HTR-10GT has different operating parameters and its core runs at a higher temperature. So thermal hydraulic safety analysis must be performed for the final safety analysis report. Under the new operating parameters, three design basis accidents were simulated with the THERMIX code system.

From the preceding analysis, it can be concluded that, in the simulated DBAs of the HTR-10GT, there is no chemical reaction in the core and the peak fuel temperature is $1201^{\circ} \mathrm{C}$, which has a tolerance to the safe margin of $1230^{\circ} \mathrm{C}$. As the spherical fuel elements containing TRISO coated particles can effectively retain radioactive fission products up to the temperature of $1620^{\circ} \mathrm{C}$ under the given normal operating conditions, there is negligible additional radioactivity release 


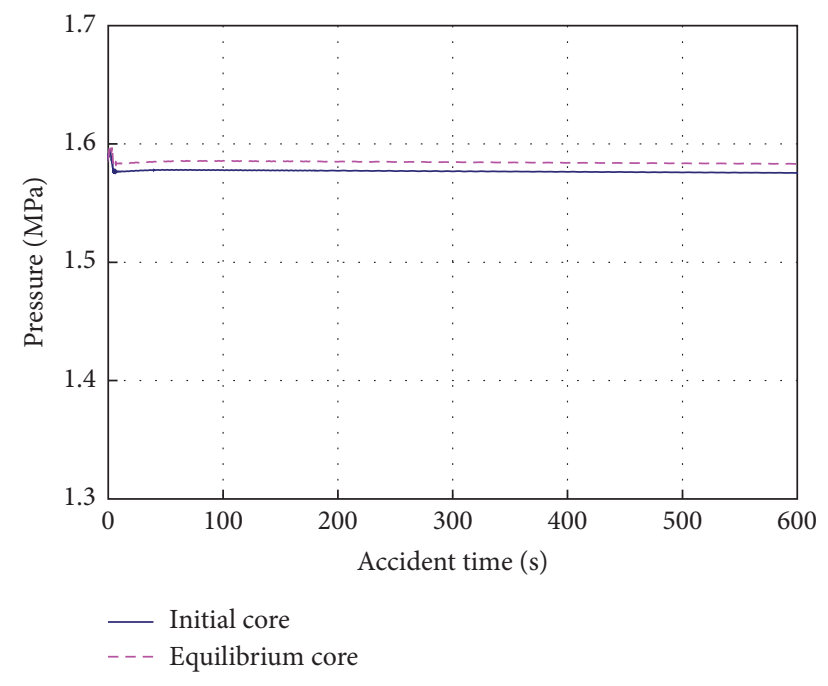

FIGURE 26: System pressure in an earthquake accident of the HTR10GT.

TABLE 7: Accident sequence of an initial core induced by earthquake.

\begin{tabular}{lcc}
\hline Events & HTR-10GT & HTR-10 \\
\hline $\begin{array}{l}\text { Densification of pebble bed } \\
\text { and positive reactivity is } \\
\text { induced }\end{array}$ & $0.0 \mathrm{~s}$ & $0.0 \mathrm{~s}$ \\
$\begin{array}{l}\text { Reactor cycle } \leqslant 20 \mathrm{~s} \\
\text { Neutron flux of power level }\end{array}$ & $0.54 \mathrm{~s}$ & $0.54 \mathrm{~s}$ \\
$\geqslant 1.23$ & $2.04 \mathrm{~s}$ & $2.54 \mathrm{~s}$ \\
$\begin{array}{l}\text { Control rods begin to drop } \\
\text { Time at which reactor power } \\
\text { reaches a peak }\end{array}$ & $3.04 \mathrm{~s}$ & $3.54 \mathrm{~s}$ \\
$\begin{array}{l}\text { Time at which fuel } \\
\text { temperature reaches a peak }\end{array}$ & $3.04 \mathrm{~s} \mathrm{~s}\left(1067^{\circ} \mathrm{C}\right)$ & $5.68 \mathrm{~s}\left(1038^{\circ} \mathrm{C}\right)$ \\
$\begin{array}{l}\text { Time at which total positive } \\
\text { reactivity reaches a peak }\end{array}$ & $150.0 \mathrm{~s}(1.24 \%)$ & $150.0 \mathrm{~s}(1.24 \%)$ \\
$(d k / k)$ & & $(15.2 \mathrm{MW})$ \\
\hline
\end{tabular}

TABLE 8: Accident sequence of an equilibrium core induced by earthquake.

\begin{tabular}{lcc}
\hline Events & HTR-10GT & HTR-10 \\
\hline $\begin{array}{l}\text { Densification of the pebble } \\
\text { bed and positive reactivity is } \\
\text { induced }\end{array}$ & $0.0 \mathrm{~s}$ & $0.0 \mathrm{~s}$ \\
$\begin{array}{l}\text { Reactor cycle } \leqslant 20 \mathrm{~s} \\
\text { Neutron flux of power level }\end{array}$ & $0.54 \mathrm{~s}$ & $0.54 \mathrm{~s}$ \\
$\begin{array}{l}\text { 1.23 } \\
\text { Control rods begin to drop }\end{array}$ & $2.54 \mathrm{~s}$ & $3.03 \mathrm{~s}$ \\
$\begin{array}{l}\text { Time at which reactor power } \\
\text { reaches a peak }\end{array}$ & $3.54 \mathrm{~s}(13.5 \mathrm{MW})$ & $\begin{array}{c}(14.0 \mathrm{~s} \\
\text { Time at which fuel }\end{array}$ \\
$\begin{array}{l}\text { temperature reaches a peak } \\
\text { Time at which total positive } \\
\text { reactivity reaches a peak } \\
(d k / k)\end{array}$ & $3.74 \mathrm{~s}\left(980^{\circ} \mathrm{C}\right)$ & $5.47 \mathrm{~s}\left(945^{\circ} \mathrm{C}\right)$ \\
\hline
\end{tabular}

expected and no fuel element damage in DBAs induced by either a station blackout, an inadvertent control rod withdrawal, or an earthquake. The HTR-10GT remains in safe condition in all three cases.

\section{Conflicts of Interest}

The authors declare that there are no conflicts of interest regarding the publication of this paper.

\section{Acknowledgments}

The authors would like to thank Professor Zhou Zhiwei and Dr. Zheng Yanhua for kindly contributing to the study. This work has been supported by the National S\&T Major Project (Grant no. ZX06901).

\section{References}

[1] G. H. Lohnert and H. Reutler, "Modular HTR—a new design of high-temperature pebble-bed reactor," Nuclear Energy, vol. 22, no. 3, pp. 197-201, 1982.

[2] H. Reutler and G. H. Lohnert, "Advantages of going modular in HTRs," Nuclear Engineering and Design, vol. 78, no. 2, pp. 129136, 1984.

[3] Y. Xu, "High temperature gas-cooled reactor programme in China," in Proceedings of International Symposia Energy Future in the Asia/Pacific Region, Taipei, Taiwan, 1999.

[4] S. Hu, R. Wang, and Z. Gao, "Safety demonstration tests on HTR-10," in Proceedings of 2nd International Topical Meeting on High Temperature Reactor Technology, Beijing, China, 2004.

[5] Z. Gao, S. He, and M. Zhang, "Afterheat removal for HTR10 test module under accident conditions," in Proceedings of Specialists Meeting on Decay Heat Removal and Heat Transfer under Normal and Accident Conditions in Gas Cooled Reactors, Juelich, Germany, 1992.

[6] Y. Dong, F. Chen, Z. Zhang et al., "Simulation and analysis of helium circulator trip ATWS test at full power on the HTR-10," in Proceedings of the 4th International Topical Meeting on High Temperature Reactor Technology, Washington, DC, USA, 2008.

[7] S. Jiang, "High temperature gas-cooled reactor project in Tsinghua University," in Proceedings of 21st-Century-COE Workshop on Energy and Environmental Issues in Asia, Kyoto, Japan, 2006.

[8] Z. Gao and L. Shi, "Thermal hydraulic transient analysis of the HTR-10," Nuclear Engineering and Design, vol. 218, no. 1-3, pp. 65-80, 2002.

[9] H. Haque, W. Feltes, M. Wickert, N. Kohtz, and J. Lukaszewicz, "Thermal response of a modular HTR under accident conditions," Nuclear Energy, vol. 22, no. 3, pp. 201-210, 1982.

[10] H. Haque, W. Feltes, and G. Brinkmann, “Thermal response of a modular high temperature reactor during passive cooldown under pressurized and depressurized conditions," Nuclear Engineering and Design, vol. 236, no. 5-6, pp. 475-484, 2006.

[11] L. Wolf, W. Scherer, W. Giesser, and W. Feltes, "High temperature reactor core physics and reactor dynamics," Nuclear Engineering and Design, vol. 121, no. 2, pp. 227-240, 1990.

[12] Y. Zheng, J. Lapins, E. Laurien, L. Shi, and Z. Zhang, “Thermal hydraulic analysis of a pebble-bed modular high temperature 
gas-cooled reactor with ATTICA3D and THERMIX codes," Nuclear Engineering and Design, vol. 246, pp. 286-297, 2012.

[13] M. Lang, "The ATWS analysis of one control rod withdrawal out of the HTR-10GT core under the loss of the system pressure," in Proceedings of 22nd International Conference on Nuclear Engineering, Prague, Czech Republic, 2014.

[14] M. Lang and Y. Dong, "The ATWS analysis of one control rod withdraw out of the HTR-10GT core in addition with bypass valve failure," Nuclear Engineering and Design, vol. 271, pp. 459464, 2014.

[15] M. Lang and Y. Dong, "The ATWS analysis of one control rod withdrawal out of the HTR-10GT core," in Proceedings of 18th International Conference on Nuclear Engineering, ICONE18, Xi'an, China, 2010. 


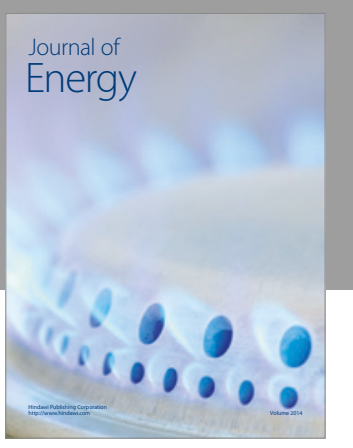

Journal of

Industrial Engineering
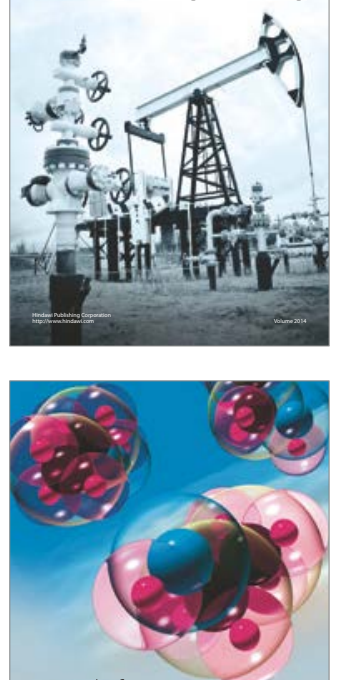

Fuels
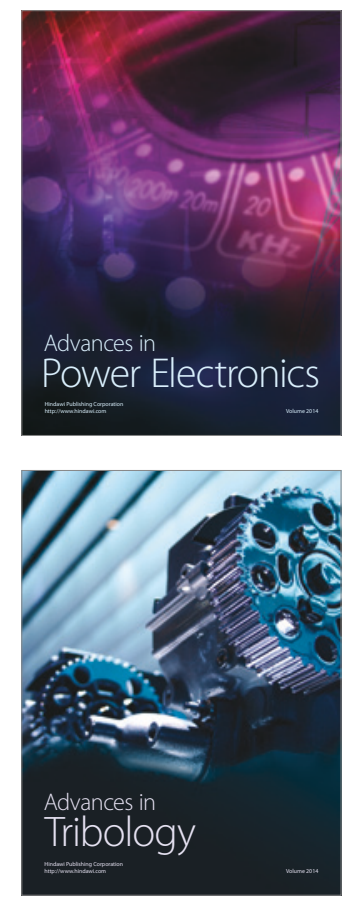
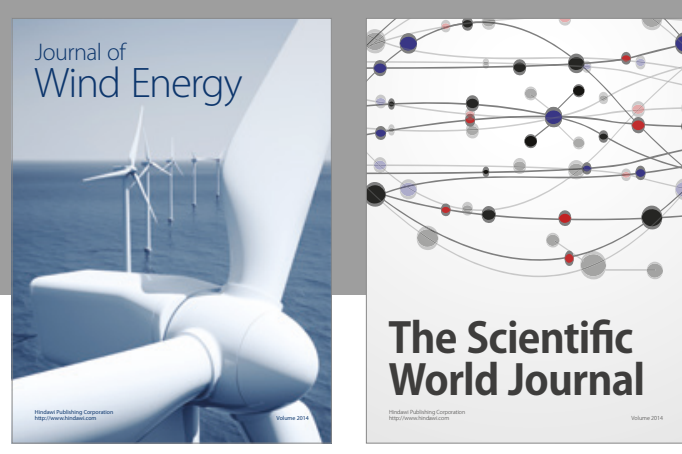

The Scientific World Journal
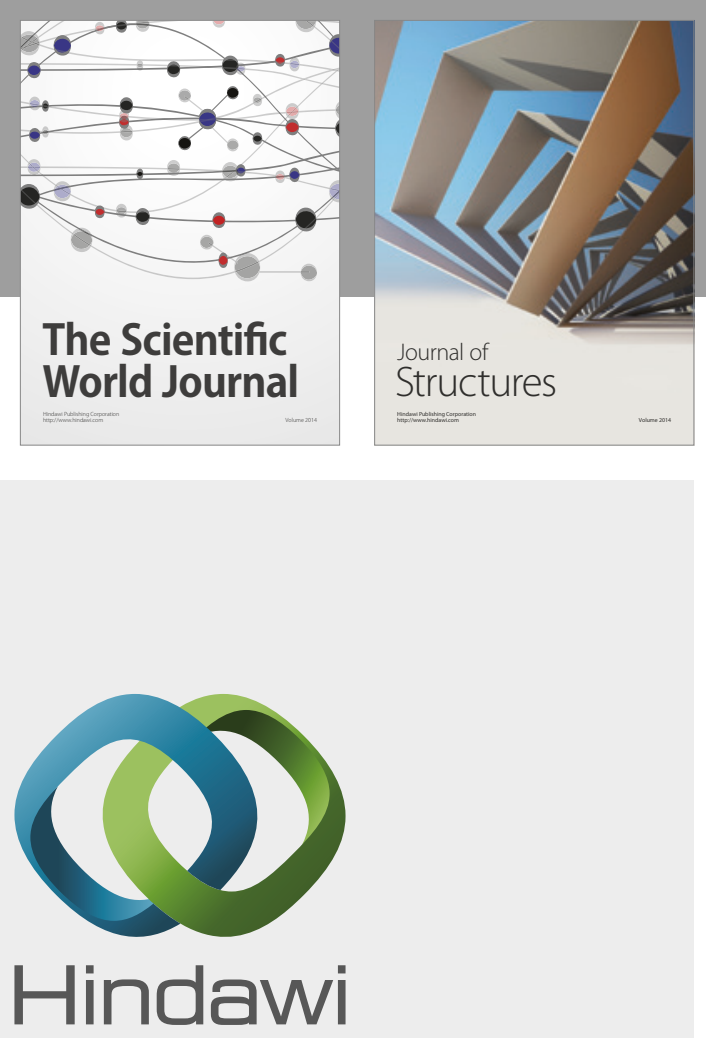

Submit your manuscripts at

https://www.hindawi.com
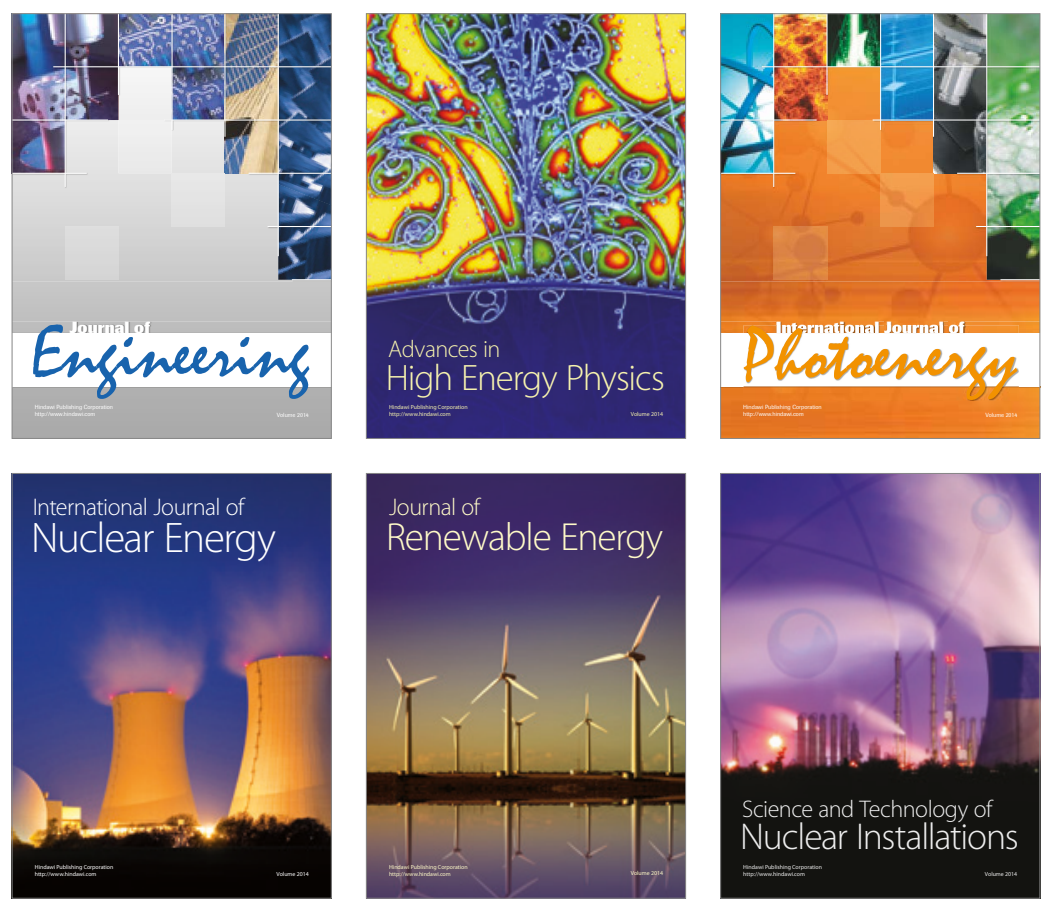

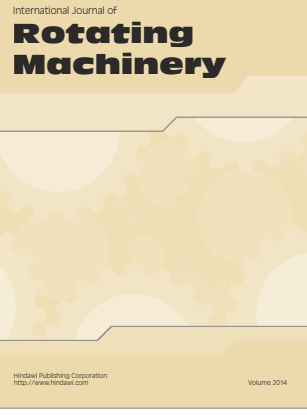

Journal of

Petroleum Engineering

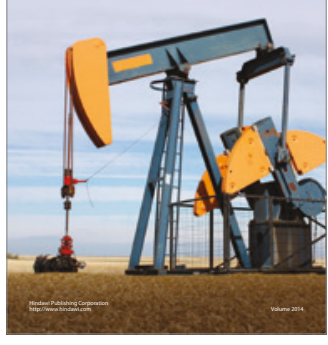

Journal of
Solar Energy
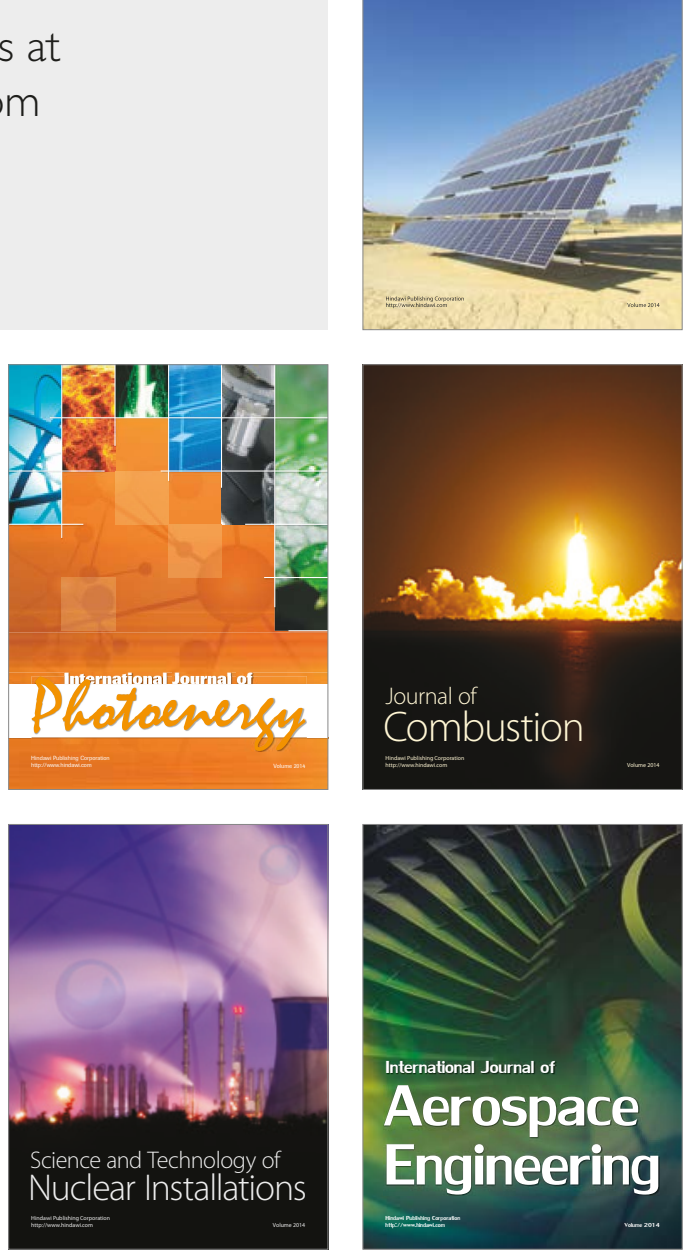